\title{
Public Policies for Agricultural Diversification: Implications for Gender Equity
}

\author{
Vivian Valencia ${ }^{1,2 *}$, Hannah Wittman ${ }^{3}$, Andrew D. Jones ${ }^{4}$ and Jennifer Blesh ${ }^{2}$ \\ ${ }^{1}$ Farming Systems Ecology Group, Wageningen University and Research, Wageningen, Netherlands, ${ }^{2}$ School for \\ Environment and Sustainability, University of Michigan, Ann Arbor, MI, United States, ${ }^{3}$ Centre for Sustainable Food Systems \\ and Institute for Resources, Environment and Sustainability, The University of British Columbia, Vancouver, BC, Canada, \\ ${ }^{4}$ School of Public Health, University of Michigan, Ann Arbor, MI, United States
}

\section{OPEN ACCESS}

Edited by: Helda Morales,

The South Border College (ECOSUR), Mexico

Reviewed by:

Marta Soler-Montiel, Sevilla University, Spain

Christopher Bacon,

Santa Clara University, United States

*Correspondence:

Vivian Valencia

vivian.valencia@wur.nl

Specialty section:

This article was submitted to Agroecology and Ecosystem Services,

a section of the journal

Frontiers in Sustainable Food Systems

Received: 31 May 2021 Accepted: 04 November 2021 Published: 03 December 2021

Citation:

Valencia $V$, Wittman $H$, Jones $A D$ and Blesh J (2021) Public Policies for Agricultural Diversification: Implications for Gender Equity. Front. Sustain. Food Syst. 5:718449. doi: 10.3389/fsufs.2021.718449
Gender equity is recognized as central to sustainable development, but women still face significant constraints in accessing and controlling productive resources important for agricultural livelihoods. Identifying mechanisms (e.g., policies and interventions) in agriculture that enhance women's empowerment - a critical aspect of gender equity - is of paramount importance for sustainable development. In this study, we investigate how Brazil's flagship targeted public food procurement program, the National School Feeding Program (PNAE), influences women's empowerment in southern Brazil. We conducted household surveys on farm characteristics and practices, women's empowerment (e.g., participation in farm decision-making and control over income), and women's participation in social movements, with farmers $(n=75)$ who do and do not participate in the PNAE. We found that women were more empowered in households participating in the PNAE, and that this empowerment was associated with diversified farming systems. When women had greater levels of participation in farm management decisions, agrobiodiversity and use of agroecological practices were higher. We also show that women's participation in agroecological social movements was associated with significantly higher empowerment (both in control over income and greater participation in decision-making). This study identifies targeted public food procurement as a promising policy instrument with potential to link cross-sectoral Sustainable Development Goals (SDGs) to sustainably increase food production (SDG 2), provide economic opportunities for small-scale farmers (SDG 1), and create an economic space that women in agriculture can more easily access (SDG 5).

Keywords: agrobiodiversity, agroecology, school meal programs, social movements, public procurement, women's empowerment, sustainable development goals

\section{INTRODUCTION}

Gender equity is an important human right and sustainable development goal, as well as a fundamental pre-condition for achieving other development objectives including improved food security, child nutrition and education, poverty reduction, and women's health (Quisumbing, 2003; Kabeer, 2010; World Bank, 2011; Gates, 2014; Cunningham et al., 2015; Malapit and Quisumbing, 2015). A critical aspect of promoting gender equity-that is, the equal enjoyment of rights, responsibilities, opportunities, and well-being between men, women, and non-binary people-is the empowerment of 
women. Empowerment describes the extent to which women are agents who can formulate choices, control resources, and enact decisions that affect important life outcomes (Kabeer, 1999; Malhotra and Schuler, 2005; Johnson et al., 2018), ultimately allowing women and men to fully participate as equal partners in productive and reproductive life.

However, women face significant challenges in their ability to access and control productive resources and opportunities that are important for agricultural livelihoods, although the nature and extent of gender inequity vary across countries, communities, and regions (FAO, 2011; Alkire et al., 2013; Agarwal, 2014; Kilic et al., 2015). In developing countries, women, on average, comprise $43 \%$ of the agricultural labor force (FAO, 2020), but are less likely than men to own land or livestock, adopt new technologies, use credit or other financial services, or receive education or agricultural extension services. Women often play a limited role in household decision-making, including about how household income is used (Head et al., 2014). Women's work in agriculture is often unpaid and focuses on the cultivation of crops for household consumption, such as in home gardens (FAO, 2020). Furthermore, when agriculture is mechanized, women's work tends to be excluded from productive activities (Kawarazuka et al., 2019).

Empowerment, broadly, often increases with participation in social mobilization that gives people a voice to demand change. In agriculture, social movements include formal and informal groups organized and led by small-scale farmers to protect their rights and further their opportunities (MartínezTorres and Rosset, 2010; Rosset and Martínez-Torres, 2012; Blesh and Wittman, 2015). Scholarship on gender in agriculture has highlighted women's exclusion from material and political processes (Allen and Sachs, 2007); in response, while not all rural and agrarian movements are feminist in orientation, the agroecology movement, particularly in Latin America, has increasingly prioritized feminist struggles in social movement formation processes (Trevilla Espinal et al., 2021), including by demanding greater recognition in agroecological spaces of praxis, science, and political formation (Prévost, 2019). For example, in the Brazilian context, it wasn't until the 1980s that some agrarian movements started adopting feminist viewpoints in their agendas (Siliprandi, 2015b). Programs and policies have emerged globally supporting women to participate in agricultural programs and access critical resources, such as land and credit (Oliver, 2016; Johnson et al., 2018). For example, social movements championing food sovereignty in Latin America have made significant gains in strengthening women's formal rights to land access (Deere, 2003, 2017).

Research has found a positive feedback between widely accepted indicators of women's empowerment-namely, decision-making and control over income-and diversified farming systems, particularly those applying agroecological practices (Hall and Mogyorody, 2007; Rosset et al., 2011; Bezner Kerr et al., 2018). Agroecological practices involve the intentional management of plant and animal diversity to support ecosystem functioning, which may eliminate or reduce the need for synthetic inputs and increase environmental sustainability (Wezel et al., 2014). Agroecological systems can improve women's position in agriculture by valuing activities traditionally managed by female farmers such as horticulture, and presenting income opportunities through venues such as farmers' markets (Siliprandi, 2015a). For example, as farms transition from conventional monocultures to diversified agroecological farming, Rosset et al. (2011) observed changes in the structure, roles and power relations within farming families, which led to greater participation and income opportunities for women and other family members. Previous work has also shown that when women make production decisions, they tend to have a positive effect on agrobiodiversity by favoring diverse food crops to support household nutrition (Oakley and Momsen, 2005; Hall and Mogyorody, 2007; Rosset et al., 2011; Bezner Kerr et al., 2018).

Although gender equity is recognized as central to increasing resilience of farms and the food system, a recent review reported that $<6 \%$ of food security publications in the previous 25 years included the topic of gender (Schipanski et al., 2016). There is a need, then, to identify mechanisms by which policies and interventions in agriculture can enhance women's empowerment (Johnson et al., 2018), and ultimately gender equity. Particularly promising are targeted public food procurement programs, which shift resources to (i.e., target) family farmers and create "structured demand"-that is, a significant and predictable demand-for locally-produced fruits, vegetables, legumes, dairy and other food products. Given their focus on diverse food items, targeted public food procurement programs can enable family farms to transition from intensive monocultures to diversified farming systems (Valencia et al., 2019). However, public food procurement remains an underexplored topic, including its relationships with farming practices and women's empowerment (Swensson et al., 2021).

This study focuses on targeted public food procurement programs that support farm diversification (Valencia et al., 2019) to investigate how public procurement may also serve as a policy mechanism to enhance women's empowerment. Our two key hypotheses are that (1) public procurement programs create an enabling social context that bolsters positive feedbacks between women's empowerment and crop diversification on farms; and, (2) this enabling context is amplified by social movements that both support agroecological farming and champion women's rights (Figure 1). Female farmers may benefit from public procurement policies that increase the economic viability of horticultural production, which otherwise represents unpaid labor to support household food consumption. By increasing the economic viability of diversified farming systems, particularly in regions where markets favor a small number of commodities and staple grains, targeted public food procurement can restructure markets to support agricultural activities in which female farmers actively participate.

We tested this framework (Figure 1) by analyzing the implementation of Brazil's National School Feeding Program (Programa Nacional de Alimentação Escolar, or PNAE, by its Portuguese acronym). The PNAE's main objective is to feed school children a healthy diet while directing at least $30 \%$ of its budget to source diversified food products from family farmers. We conducted this research in the state of Santa 


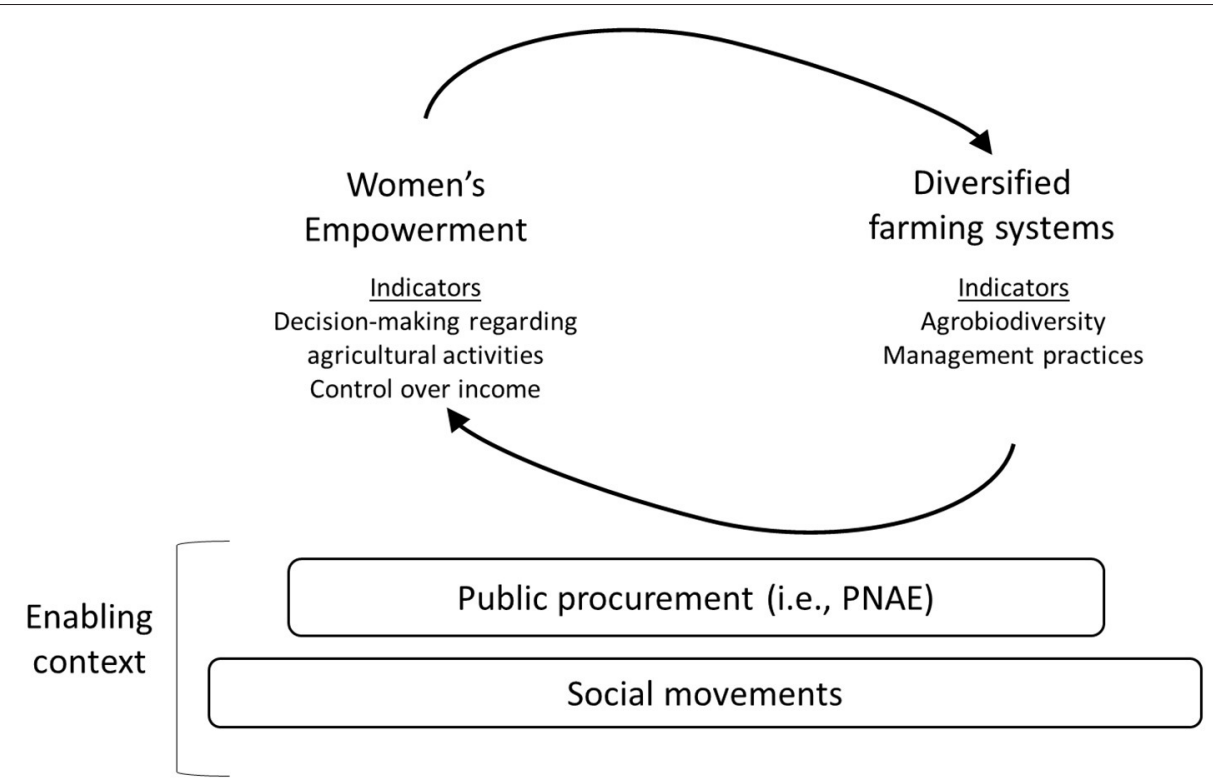

FIGURE 1 | Focusing on targeted public food procurement programs that support farm diversification, we hypothesize that public procurement programs create an enabling social context that bolsters positive feedbacks between women's empowerment and crop diversification on farms; and that this enabling context is amplified by social movements.

Catarina in southern Brazil, where the regional implementation of PNAE has been particularly successful in meeting its food procurement goals compared to other regions of Brazil (FAO, 2014; Schneider et al., 2016). Analyzing a case study in this region allowed us to explore the potential of public procurement programs to enhance the links between women's empowerment and farm diversification. In the following sections, we discuss how we conceptualized and measured women's empowerment; we elaborate on the conceptual linkages between public food procurement and sustainable development; and describe the evolution of the PNAE program in Brazil over the last decade.

\section{Women's Empowerment}

Empowerment is defined as increasing the capacity for people to make choices and transform them into desired outcomes (Kabeer, 1999). Specifically, empowerment spans three key dimensions: resources (material, human, and social resources which enhance the ability to make choices), agency (the ability to define one's goals and act upon them, often operationalized as decision-making) and achievements (wellbeing outcomes) (Kabeer, 1999). The process of empowerment, in which an individual accesses resources and applies them to achieve a meaningful outcome, is critical for achieving gender equity. Although the terms equality and equity are often used interchangeably, they are distinct (Leach et al., 2018). Equality means that resources and opportunities are evenly distributed (i.e., equal treatment), whereas equity involves shifting resources to account for inequality, and better incorporates the concept of justice. We use the term equity in this paper, in part because we focus on a "targeted" policy program that seeks to shift resources and opportunities to increase fairness and improve well-being of marginalized groups.

Empowerment of individuals is influenced both by agency and by the "opportunity structure" of a society; that is, the social and institutional context, including policies, cultural norms, and markets, which also shape access to resources (Narayan, 2005; Ibrahim and Alkire, 2007). Example opportunity structures that influence women's empowerment include family systems, policy conditions and infrastructure, gender ideologies, and regional or local market processes (Malhotra and Schuler, 2005). Structural conditions define the parameters within which different actors can pursue their ambitions, inhibiting the agency of some while promoting that of others. Structural inequities constrain women's ability to make strategic life choices, while institutional changes that are inclusive of women may increase empowerment.

Women's empowerment thus often depends on collective action to change the structures that perpetuate unequal power relations (Narayan, 2005), and women's organizations and social movements have played an important role in creating conditions for change and in facilitating the agency of individuals (Kabeer, 1999). In Latin America, social movements have been crucial for women to attain formal land rights, both in constitutional reforms and in practice. In the late 1990s in Brazil, participation of women within social movements was key for more women to benefit from land reforms (Deere, 2003). Social movements such as the Landless Workers' Movement (Movimento dos Trabalhadores sem Terra) began to more explicitly address gender concerns as part of their political strategy, arguing that a failure to recognize women's land rights was detrimental to attaining the movement's goals 
(Deere, 2003). In Brazil specifically, women's and gender rights mobilizations were rooted in the spread of rural feminism (Butto, 2019), and engaged with the state in developing new institutions, including the National Council for Food and Nutrition (Conselho Nacional de Segurança Alimentar e Nutricional, CONSEA). Mobilizations by the MST, the Peasant Women's Movement (Movimento das Mulheres Camponeses, $M M C$ ), and other movements associated with La Vía Campesina led to the development of specific rural credit programs for women (PRONAF), as well as incentives for women's participation in public procurement programs such as the Food Acquisition Program (Programa de Aquisição de Alimentos, PAA) and the PNAE, which increased support for the marketing of food products that tend to predominantly involve-and make visible-women's labor, including horticulture and processed foods (Grisa and Isopo Porto, 2015; Siliprandi and Cintrao, 2015).

In this study, we focus on women's empowerment in farming households in Brazil within the broader context of two key institutions, the PNAE and social movements. We draw from the Abbreviated Women's Empowerment in Agriculture Index (A-WEAI), which is a survey-based tool designed to measure the empowerment, agency, and inclusion of women in the agricultural sector (Malapit et al., 2015). The A-WEAI includes five domains, each with its corresponding indicator, which reflect aspects of empowerment found in the literature: (1) decisions about agricultural production, (2) access to and decision-making power about productive resources, (3) control of use of income, (4) leadership in the community, and (5) time allocation (Alkire et al., 2013). We focus on domains 1 and 3 because we are particularly interested in how women's decision-making regarding agricultural production and control over use of income impact agrobiodiversity and agricultural practices. Moreover, the first domain directly follows from definitions of empowerment as the ability to make choices (Kabeer, 1999; Alsop et al., 2006), in this case about agricultural production. Control over income is key for exercising agency and reflects whether an individual is able to benefit from their efforts. We also consider domain 4 (leadership in the community) with respect to groups that support agroecology because we are interested in the role of social movements in supporting a transformation toward sustainable food systems.

\section{Public Procurement and Sustainable Development}

Public procurement constitutes a powerful policy mechanism for sustainable development by leveraging the purchasing power of the state to restructure production and consumption patterns. Estimates suggest that public procurement comprises up to $16 \%$ of the GDP in the European Union, while in OECD countries it ranges between 5 and $20 \%$ (Brammer and Walker, 2011; OECD, 2017). The potential of targeted public procurement to promote sustainable development is recognized in SDG 12 "Sustainable Consumption and Production Patterns," particularly in target 12.7 to "promote public procurement practices that are sustainable."

Targeted public food procurement establishes what types of food will be purchased (e.g., local, diverse), from whom it will be purchased (e.g., local farmers, women), and the production systems from which it will be purchased (e.g., organic systems) (Swensson et al., 2021). Depending on how these choices are made, governments can tailor public food procurement to policy and social welfare objectives and pursue outcomes, from localizing food systems to supporting the participation of marginalized groups. We suggest, as a theory of change, that public procurement can improve sustainability in food systems by offering:

(1) A large, predictable, and reliable demand for agricultural products that reduces risks and uncertainties associated with commodity markets;

(2) A reliable source of income generation through the creation of favorable market conditions, particularly for family farmers;

(3) Price stabilization through establishment and negotiation of prices;

(4) Incentives or requirements for meeting voluntary sustainability standards in production (e.g., organic) and value chain governance (e.g., Fair Trade);

(5) A demand for diversified food products (e.g., vegetables, legumes, dairy).

Points 1-3 characterize structured demand (Sumberg and Sabates-Wheeler, 2011; Commandeur and Casey, 2016; Nehring et al., 2017). By creating reliable demand for products grown by smallholder or family farmers, structured demand programs in theory improve food systems by reducing market risk and increasing production and supply chain quality (Coles, 2013). Sources of structured demand include schools, hospitals, the military, and food aid programs. In this form of market, the state mediates supply and demand relationships to drive systemic changes needed to increase market access for smallholder farmers (Wittman and Blesh, 2017). Through government intervention, markets are redesigned to be more "socially efficient" and fair, particularly for supporting food security and other basic social welfare needs (Rocha, 2007). The result is a more accessible, less risky, and more profitable market for farmers to produce food for local and regional consumers (Sumberg and Sabates-Wheeler, 2011).

\section{The National School Feeding Program (PNAE)}

Brazil's long-standing National School Feeding Program (PNAE) was redesigned in 2009 to link objectives in food security, education, and rural development, as part of a broader food security strategy based on the creation of new markets driven by public procurement (Schneider et al., 2016). School feeding programs based on targeted procurement, such as PNAE, aim to increase children's consumption of locally and regionally procured food. The focus on locally produced food reflects increasing understanding of the potential benefits to farmers, traders, and consumers of localized procurement strategies 
(Sumberg and Sabates-Wheeler, 2011). The PNAE is a decentralized program operating at the municipal level.

Since 2009, the PNAE has included a budget benchmark of at least $30 \%$ for purchasing food from family farmers within a school's municipality, recognizing the importance of family farmers for meeting national food security needs. Even more relevant to expanding the presence of diversified farming systems, the Brazilian government provides direct incentives for certified organic and agroecological food products through this program (Law No. 12.512, 2012; Resolution No. 26, 2013). PNAE provides up to a $30 \%$ price premium for certified organic and agroecological products and prioritizes contracts for certified production (Sidaner et al., 2013). Participatory certification programs that allow peer-to-peer certification and monitoring of practices within farmer networks have been key in supporting the expansion of agroecological practices (Abreu et al., 2012; Guerra et al., 2017). These certification schemes have lower barriers to entry for family farmers (Abreu et al., 2012; Barrett et al., 2012; Guerra et al., 2017) and support practices such as reducing or eliminating chemical fertilizers, preserving native forest, increasing biodiversity, and planting organic seeds (Guerra et al., 2017). Through these innovative mechanisms, PNAE has created a unique market for family farmers to sell diversified food and agricultural products (Wittman and Blesh, 2017; Valencia et al., 2019).

Political mobilization by social movements played a central role in triggering the redesign of PNAE to also benefit family farmers, and especially women farmers. Until the 1990s, public policies in the agricultural sector were largely focused on supporting medium and large export-oriented farms by, for example, offering subsidized credits and capital investment projects (Medina et al., 2015). These credit instruments were practically inaccessible to family farmers. In the $1980 \mathrm{~s}$ and 1990s, family farmers and landless workers started to emerge as a political force playing an important role in the democratization of Brazil (Wolford, 2010; Grisa and Schneider, 2014). In the 1980s, the Landless Workers Movement mobilized government support for land distribution, while in the 1990s, rural and social movements began a joint campaign demanding government action in response to increasing levels of hunger and malnutrition (Mendonça Leão and Maluf, 2003; Schneider et al., 2010; Rocha et al., 2012). This resulted in a series of programs and policies, such as PNAE, based on the creation of institutional markets aimed at food security and environmental sustainability (Grisa and Schneider, 2014).

Political will was also fundamental to modifying the legal framework to enable innovations in public procurement in Brazil. Typical public procurement procedures follow a bidding process to ensure transparency and reduce discrimination and corruption in government spending. However, the bidding process presents a legal obstacle to family farmers, who cannot easily compete with larger producers due to its formality, complexity, and technical requirements (Müller et al., 2007; Takagi et al., 2014). To facilitate participation of family farmers, it was necessary to adapt the procurement procedure to suit the capabilities and characteristics of family farmers by waiving the bidding process to create a direct procurement mechanism (Swensson, 2015).

\section{MATERIALS AND METHODS}

\section{Study Area}

The study took place in 2016 in the municipalities of Curitibanos, Correa Pinto, and São Jose do Cerrito in the plateau region of Santa Catarina state in southern Brazil. The study municipalities include a range of farming systems that span soybean, garlic, bean, and corn monocultures; livestock production (e.g., chickens, pigs, dairies); and diversified horticultural crops for both household and market purposes. Markets for soybean, garlic, beans, and corn include regional, national, and international markets, while corn is often produced to feed farmers' own livestock. Typical markets for horticulture crops include local markets such as PNAE, restaurants, and farmers' markets. In Santa Catarina, family farmers comprise $85 \%$ of farming establishments with an average farm size of 28.8 hectares (IBGE, 2006). By family farmers, we refer to a farming property that preferentially employs family members and whose income is derived predominantly from farming. This is in line with Brazil's legal definition of family farmers, which is based on four criteria: a maximum land tenure defined regionally; a predominant recourse to non-wage family labor; an income mainly originating from the farming activity; and a farm operated by the family. Santa Catarina ranks highest in the Human Development Index (HDI) after Brazil's Federal District and the state of São Paolo (UNDP., 2016), a level higher than most Latin American countries and corresponding to one of the highest levels of education and literacy in Brazil (IBGE, 2013; SEBRAE, 2013). As in other southern Brazilian states, the racial and gender inequity in wages, education, and occupation is smaller relative to the North of the country (Lovell, 2000). This region is also characterized by more favorable conditions for agriculture compared to other regions of Brazil, including greater access to agricultural credit and infrastructure (Medina et al., 2015).

Santa Catarina is one of the states where PNAE has most successfully met its food procurement objectives. Based on data obtained from FNDE (2018), we calculated that across municipalities in Santa Catarina, on average, 50\% of school meal funding was invested in acquisitions from family farmers, thereby exceeding the minimum $30 \%$ commitment required by law. In contrast, for all of Brazil, we calculated that only $49 \%$ of municipalities meet the minimum (30\%) requirement. The other half may not meet this requirement because there are not enough family farmers in the municipality to supply demand, or due to other barriers that prevent participation, such as long distances between farms and food purchasing centers, or poor road infrastructure. The success of PNAE in Santa Catarina is recognized by the United Nations Food and Agriculture Organization, who used this case as a model informing the design and implementation of feeding programs based on targeted public food procurement (FAO, 2014). Focusing this study on a region with robust PNAE policy implementation allowed us 
to explore the potential of public procurement in supporting women's empowerment.

\section{Data Collection}

To develop the case study, we interviewed members of 20 family farms in our study region who were participating in PNAE. This sample came from a total group of $\sim 25$ family farms enrolled in PNAE in the three municipalities, which we identified via interviews with key informants at local government agencies in each municipality, and farmers' organizations who had official lists of farmers participating in PNAE. Although more than 25 individuals were officially registered in PNAE in the study area, occasionally multiple members of the same household were registered in the program but were associated with the same farming unit. In those cases, we did not "double count" those farmers, but included them in the final sample of 20 family farm households participating in PNAE. We also interviewed members of 55 family farms not participating in PNAE, which were selected to represent the diversity of cropping systems in the region while also minimizing variation in other factors across farms (e.g., soil and climate conditions). We identified non-PNAE family farms with recommendations from key informants combined with snowball sampling.

Surveys to assess women's empowerment and participation in social groups that promote the use of agroecology were directed to the female farmer head of household for all 75 farms. Female farmers were interviewed by female interviewers to help ensure that respondents felt comfortable answering questions related to empowerment. Surveys on management and farm characteristics were directed to the head of household responsible for management. Although management surveys were primarily answered by the male farmer head of household, female farmers were also present and contributed information. Management surveys collected data on farm management, including agrobiodiversity; use agrochemicals and other inputs; extent of mechanization; agroecological certification status, and markets where each product was sold, including PNAE. At the end of each interview, we conducted visual inspection of farms alongside with farmers to corroborate responses on farm agrobiodiversity and management practices; on a few occasions, observed crops had been omitted by respondents during interviews and these were added to the list by the interviewer.

We also conducted key informant interviews with seven female community leaders to gain in-depth understanding of the links between PNAE, social movements, women's empowerment, and farm diversification. Specifically, we discussed the role of female farmers in decision-making about farm diversification in response to market demands created by PNAE, and the role that social movements played in this process. In addition to community leaders in the study site, key informant interviews also included leaders of the Movement of Rural Women (Movimento de Mulheres Camponesas) in their offices in Western Santa Catarina; although outside of the study site, these interviews provided valuable contextual information. Key informant interviews were open-ended conversations that lasted between 60 and $120 \mathrm{~min}$. Key informant interviews were conducted by the primary author; surveys were conducted by the primary author and a team of six trained enumerators.

\section{Women's Empowerment}

We used the questionnaire developed for the Abbreviated Women's Empowerment in Agriculture Index (A-WEAI) to collect data to calculate indicators for two key dimensions of empowerment: (i) female farmers' participation in decisions about agricultural production and (ii) control over use of income (Malapit et al., 2015). We also used the questionnaire developed by A-WEAI to assess leadership in the community, with a specific focus on female farmers' participation in social groups that support knowledge sharing and promotion of agroecological practices.

The A-WEAI was developed and calibrated with data from pilot studies in countries such as Bangladesh and Uganda. At the time of this study, the thresholds of empowerment for these indicators had not been calibrated for middle income countries characterized by higher development metrics (e.g., literacy rates, Human Development Index), such as our study area. We therefore used the A-WEAI survey instrument without applying the proposed thresholds for empowerment. Furthermore, in the original A-WEAI survey, when asked questions about who makes decisions, respondents may only choose "self," "spouse," "other household member," or "other non-household member." Yet based on observations during pilot testing, we noted that joint decision-making between male and female heads of household was a common decision-making strategy in our study region. Consequently, we added another option for respondents: "both my spouse and me." Other studies have also identified jointdecision making as important to farming households (Acosta et al., 2019).

We assessed female farmers' participation in decision-making, and control over use of income, for horticultural plots on the farm-regardless of whether production was for homeconsumption or markets-and for the primary agricultural activity as defined by household members, if different from horticulture (e.g., soybean, garlic, dairy). The questionnaire collected the following data from the female farmers who indicated actively participating in a given agricultural activity: who was in charge of decision-making (i.e., "self", "spouse," "self and spouse," "other household member," or "other nonhousehold member"); and how much the female farmer participated in decision-making (i.e., not at all to very little; in some decisions; in most decisions; no decisions were taken). Finally, regarding control over income, we asked how much the female farmer contributed to decision-making on the use of the income generated by the agricultural activity in question (i.e., not at all to very little; in some decisions; in almost all decisions; no decisions were taken).

\section{Agrobiodiversity}

We calculated food species (plants and livestock combined) richness for the entire farm and plant species richness for the horticulture plot. Crop species and varieties included fruit trees, vegetables, tubers, and legume grains; livestock species included cows, pigs, chickens, turkeys, rabbits, and other animals. We used 
the package Biodiversity. $\mathrm{R}$ in the statistical software $\mathrm{R}$ to calculate richness metrics (Kindt and Coe, 2005).

\section{Agroecological Practices}

As a proxy for application of agroecological practices, we developed an external input intensity indicator following Garibaldi et al. (2016), and applied in Valencia et al. (2019). The indicator was constructed by adding +1 for each input purchased or acquired from off the farm; -1 for each input or organic amendment (e.g., compost, legume cover crops) acquired from the farm based on farmers' own resources; and -0.5 for amendments or pest control products made from both internally and externally acquired ingredients. This indicator captures the goal of agroecological practices to reduce use of off-farm inputs by managing plant diversity (e.g., cover crops or intercrops), or integrated crop-livestock systems for greater ecological function. The indicator values ranged from -5 to +7 , where more negative values (i.e., lower input use intensity) reflect greater use of onfarm resources and agroecological management. The indicator was calculated both at the field level (e.g., horticulture plot) and whole farm level by weighting each field's indicator by the farm's total cropped area.

\section{ANALYSES \\ Institutional Demand for Diversified Food Products and Women's Empowerment}

We assessed how PNAE's demand for diversified foods affects women's empowerment. We compared households enrolled and not enrolled in PNAE to investigate the association with two domains of women's empowerment: female farmers' participation in decision-making about agricultural activities, and control over use of income. We used Fisher's exact test to assess if differences between PNAE and non-PNAE were statistically significant, followed by a pairwise comparison by using the Benjamini and Hochberg (1995) correction. All statistical analysis were conducted in the statistical software $\mathrm{R}$ (Kindt and Coe, 2005). Values are reported as significant at $p$-values $<0.05$.

\section{Women's Empowerment, Agrobiodiversity, and Agroecological Practices}

We examined how female farmers' participation in decisionmaking about agricultural activities affected agrobiodiversity and agroecological practices. We applied ANOVAs followed by Tukey's HSD to test if agrobiodiversity (measured by richness in both the entire farm and horticulture plots) and the external input intensity indicator were related to: whether female farmers participated (yes or no) in decision-making about the main agricultural activity or horticulture plot (regardless of whether horticulture was the main agricultural activity, or primarily for household consumption); degree of female participation (limited, moderate, or considerable) in decision-making about the main agricultural activity or horticulture; and the person in charge (female, male, or both) of decision-making about the main agricultural activity or horticulture plot. We also conducted a linear regression in which richness in the horticulture plot was the dependent variable, and as explanatory variables we included the primary person in charge of the horticulture plot (female, male, or both), and whether the household was part of PNAE, while controlling for the size of the horticulture plot.

\section{The Role of Social Movements}

We tested the role of social movements in enabling: (1) farmers' participation in public programs such as PNAE and (2) women's empowerment. For (1), we compared female farmers' participation in social movements between households enrolled and not enrolled in PNAE by conducting a Welch two-sample $t$ test and two-sample Wilcoxon tests when data did not meet the assumptions of normality. We checked for normality using the Shapiro-Wilk test. For (2), we conducted Fischer's exact tests to compare whether participating (or not) in social movements was associated with: who was in charge of decision-making; to what extent the female farmer participated in decision-making; and, how much the female farmer contributed to decision-making about the use of income generated by the main agricultural activity. For contingency tables of $2 \times 3$, we conducted post-hoc multiple pairwise comparisons and adjusted $p$-values by using the Benjamini and Hochberg (1995) correction.

\section{Qualitative Analysis}

Following a mixed methods approach, during each key informant interview, the primary author took detailed notes. Notes were then transferred into summary sheets, from which we summarized the main findings and key themes of each interview. Summary sheets were analyzed to identify recurrent explanations and themes. The qualitative analysis was used to generate contextual information to help interpret statistical results (Blesh and Wittman, 2015).

\section{RESULTS}

\section{Institutional Demand for Diversified Food Products and Women's Empowerment}

Key informant interviews with female community leaders suggested that female farmers played a mediating role in the process of farm diversification in households enrolled in PNAE. That is, female farmers supported the transition of a household's primary focus from grains or other monoculture systems to diversified farming systems (i.e., horticulture), primarily managed without mechanization. This was because women, who were typically in charge of cultivating home gardens to support a household's self-provisioning, perceived PNAE as a market opportunity from which they could generate an income. The alternative markets for horticultural products primarily included restaurants and small local farmers' markets, which are highly variable in terms of size and stability of demand. Key informants also explained that because the expansion of horticultural production implied a shift of resources (e.g., labor, inputs, time) from the primary activity (often corn and bean monocultures) to horticulture, female farmers played a role in overcoming their household's resistance and anxiety vis-à-vis engaging with a new market. As recounted in multiple interviews, female farmers needed to persuade the male head of household to 


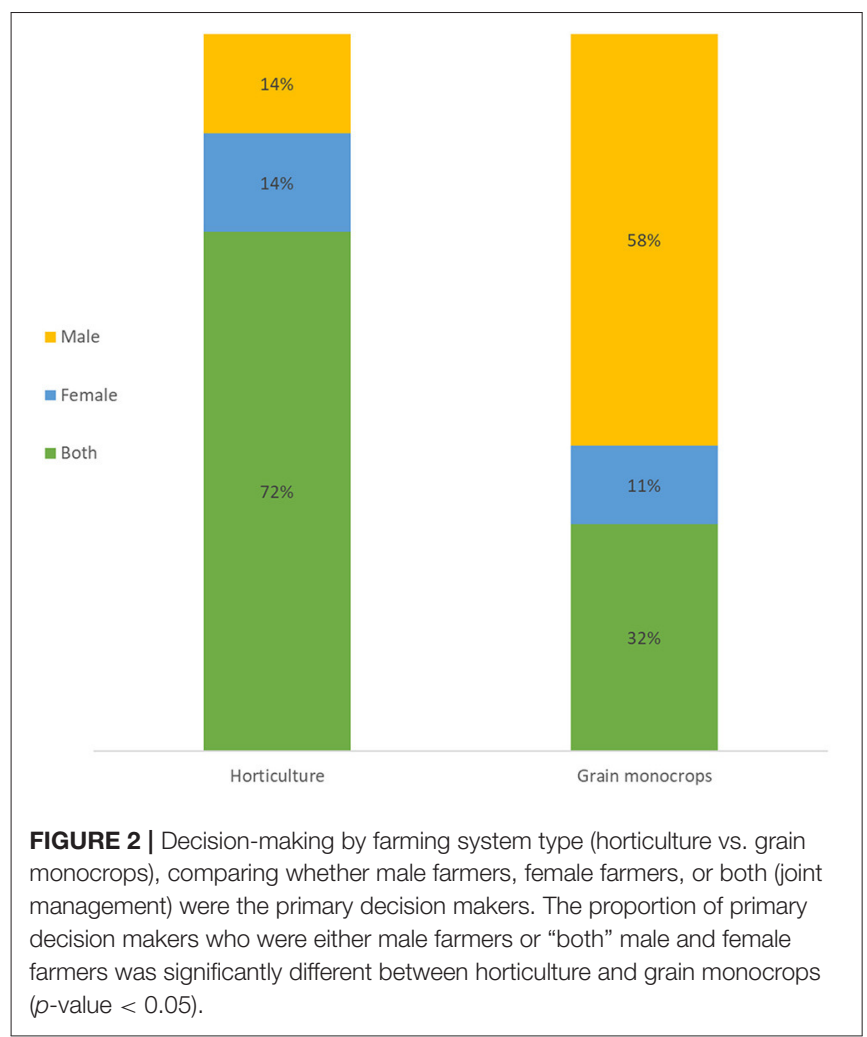

support expanding the horticulture plot from a home garden to a larger, market-oriented field capable of meeting PNAE's demands for vegetables, tubers, legumes, and other products.

Expanding horticultural production to participate in PNAE also shifted women's role from previously tending a home garden, or small plot for household consumption, to involvement in decision-making for a market-oriented plot, which in many cases became the main agricultural activity of the household. Female farmers' participation in production decisions in households with horticulture as the main agricultural activity was significantly higher than in households where grains dominated because male farmers typically managed grain cropping systems ( $p$-value $<0.05)$. The difference was primarily evident in the higher proportion of women involved in "joint" decision-making (72 vs. $32 \%, p$-value $<0.05$ ), and in the lower proportion of men (14 vs. $58 \%, p$-value $<0.05)$ as the sole decision-makers in horticulture vs. grain monocrop households (Figure 2).

All female farmers in the PNAE group reported actively participating in the main agricultural activity, compared to $80 \%$ of non-PNAE female farmers ( $p$-value $<0.05)$. Among female farmers who actively participated in the main agricultural activity, there was a marginally significant difference between the PNAE and control group regarding who made decisions concerning that activity ( $p$-value $=0.06$ ) (Figure 3 ), but there were no significant differences regarding control over income. Specifically, for PNAE farmers, most decisions (70\%) were made jointly by males and females, while for non-PNAE farmers joint decision making occurred in half the cases (51\%). For

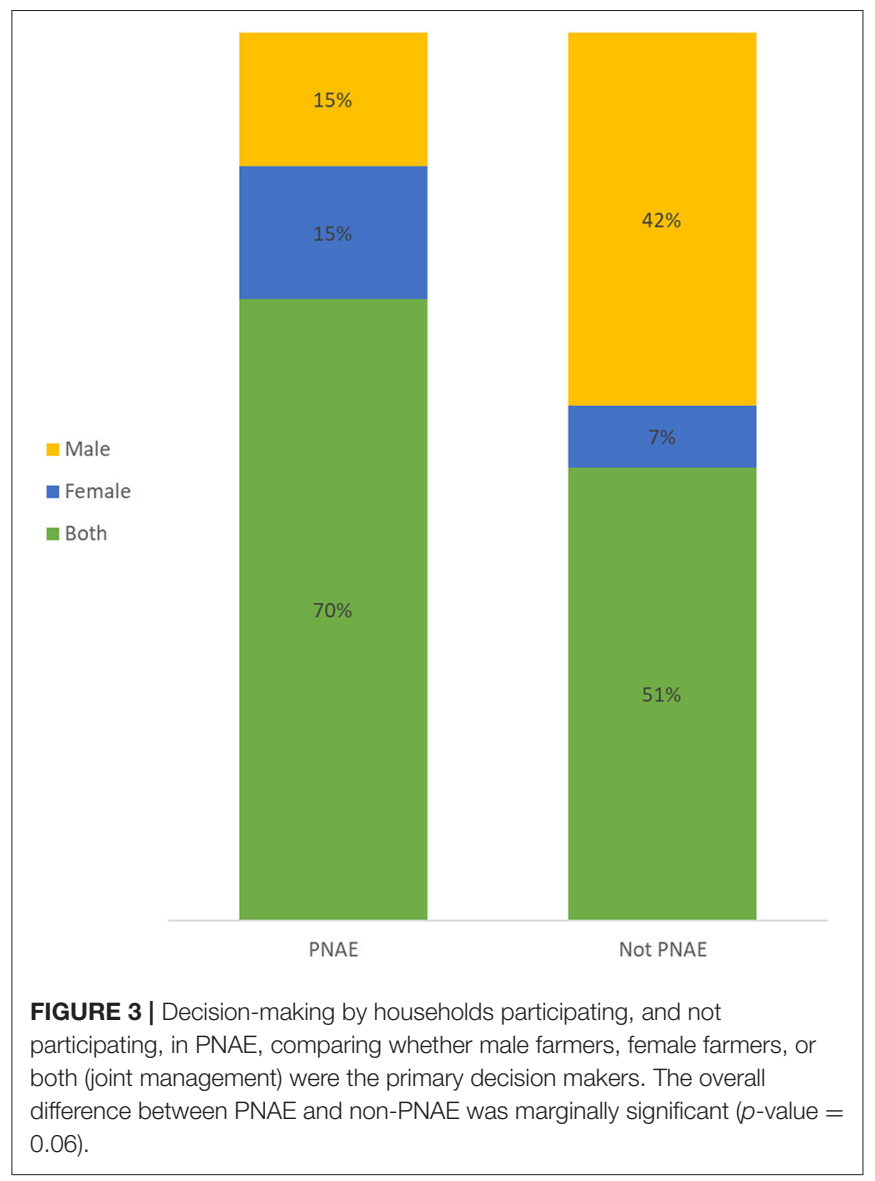

non-PNAE farmers, $42 \%$ of primary decision-makers were male farmers, whereas this only rarely occurred (15\%) among male farmers in PNAE. In both groups, female farmers were the primary decision-makers in just a few cases (15\% in PNAE; $7 \%$ control group).

\section{Women's Empowerment, Agrobiodiversity, and Agroecological Practices}

Results from ANOVA models (Table 1) indicated that when female farmers did not participate in decision-making for horticulture crops, whether as the main activity or a plot for home consumption, horticulture richness was halved ( $p$-value $<0.01$ ). The same effect was detected on richness for the entire farm, although it was only marginally significant $(p$-value $=0.05)$. We also found that when the horticulture plot was managed by both the male and female farmers, crop richness, on average, was $50 \%$ greater $(p$-value $<0.05)$ compared to when it was just managed by either one alone (see Table 1). Furthermore, when only the female farmer, or both the male and female farmers, managed the main agricultural activity, the external input intensity indicator was significantly lower than when only the male farmer managed in isolation ( $p$-value $<0.0001)$.

Results of linear regression showed that participation in PNAE was the strongest, positive predictor of horticulture richness ( $p$ value $<0.0001)$ and of total farm richness $(p$-value $<0.05)$. 
TABLE 1 | Relationship between agrobiodiversity and indicators of women's empowerment. Reported values are means followed by standard deviation in parenthesis.

\begin{tabular}{|c|c|c|c|c|c|c|c|c|c|c|}
\hline \multirow[b]{2}{*}{ Indicator } & \multirow[b]{2}{*}{ Level } & \multicolumn{3}{|c|}{$\begin{array}{l}\text { Female participation in } \\
\text { decision-making for main activity }\end{array}$} & \multicolumn{3}{|c|}{$\begin{array}{l}\text { Female participation in } \\
\text { decision-making in horticulture plot }\end{array}$} & \multicolumn{3}{|c|}{$\begin{array}{c}\text { Who is primarily in charge of } \\
\text { horticulture plot }\end{array}$} \\
\hline & & Yes $(n=64)$ & No $(n=11)$ & $P$-value & Yes $(n=66)$ & No $(n=9)$ & $P$-value & Both $(n=38)$ & $\begin{array}{l}\text { Female } \\
(n=20)\end{array}$ & Male $(n=17)$ \\
\hline \multirow[t]{2}{*}{ Richness } & Horticulture plot & $6.8(3.8)$ & $2.5(2.2)$ & 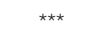 & $6.6(3.9)$ & $3.2(1.6)$ & $\star \star$ & $7.5(4.0)^{b}$ & $4.7(3.1)^{\mathrm{a}}$ & $5.1(3.5)^{\mathrm{a}}$ \\
\hline & Farm & $19.4(5.7)$ & $15.8(4)$ & $\bullet$ & $19.0(5.8)$ & $17.1(3.8)$ & N.S. & $19.5(6.2)^{\mathrm{a}}$ & $20.6(5.2)^{a}$ & $17.2(4.4)^{\mathrm{a}}$ \\
\hline \multirow{2}{*}{$\begin{array}{l}\text { External input } \\
\text { intensity }\end{array}$} & Horticulture plot & $-2.0(1.3)$ & $-0.4(2.1)$ & $\star \star$ & $-1.8(1.6)$ & $-1.7(0.7)$ & N.S. & $-1.9^{a}$ & $-1.7^{\mathrm{a}}$ & $-1.5^{\mathrm{a}}$ \\
\hline & Farm & $-0.6(3.1)$ & $2.7(2.0)$ & $\star \star$ & $-0.26(3.1)$ & $2.7(2.9)$ & * & $-1.3^{\mathrm{a}}$ & $-1.2^{\mathrm{a}}$ & $1.7^{b}$ \\
\hline
\end{tabular}

For multiple comparisons, mean values in rows with the same letter do not differ significantly ( $p$-value $<0.05)$.

${ }^{* \star *} p$-value $<0.001$

${ }^{* \star} p$-value $<0.01$

${ }^{*} p$-value $<0.05$.

$\bullet p$-value $=0.05$.

N.S. $p$-value $>0.05$.

Management by the female or male farmer alone was a negative predictor of horticulture richness $(p$-value $<0.05)$ compared to joint management, which tended to have a positive, but not statistically significant, relationship in linear regression.

\section{The Role of Social Movements}

Our analysis of the role of social movements identified two key groups that promoted agroecological practices in the region (henceforth "agroecological social movements"). One group was a local NGO actively engaged in particular communities in the study region, which leads programs to support the dissemination of knowledge about agroecological practices, and helps family farmers attain and retain certification for organic production. Women were actively encouraged by the NGO to participate in trainings and workshops; $23 \%$ of the women farmers interviewed for the study participated in activities led by this group, but not all interviewed farmers knew of its existence or participated. The second group was the Movement of Rural Women (MCC); about a third of female farmers in the study sample were engaged with the movement. Other groups in the region supported agroecological practices, but not exclusively; that is, they also provided technical assistance for other types of farming (e.g., garlic, corn, and soy monocultures). For example, the cooperative-based rural bank and the state's extension agency both played a role in supporting agroecological farmers, but also provided technical assistance and financial support for conventional management systems. These other groups were not included in the category "agroecological social movements" in our analysis.

We found that $65 \%$ of PNAE households participated in agroecological social movements compared to $40 \%$ of nonPNAE farmers (marginally significant difference, $p$-value $=0.06$ ). Additionally, households in which female farmers participated in agricultural programs led by the local NGO were $\sim 7$ times more likely to be enrolled in PNAE than those not participating in these NGO programs (odds ratio $=6.63 ; 95 \% \mathrm{CI}$ : $1.8,26.4$; $p$-value $<0.001)$.

Across the entire sample (both PNAE and non-PNAE participants), most women (85\%) actively participated in the main agricultural activity; among these women, half (47\%) also participated in agroecological social movements while the other half $(53 \%)$ did not participate. When we compared these latter two groups, we found greater participation in decision-making regarding main agricultural activities ( $p$ value $<0.01$ ) and a higher control over income ( $p$-value $<0.01)$ for the women who participated in agroecological social movements.

\section{DISCUSSION}

To understand how public policies that increase farm diversification can also support women's empowerment in agriculture, we evaluated links between targeted public food procurement and gender dynamics. The PNAE public food procurement program targets family farmers and other marginalized social groups by creating a large and reliable (i.e., "structured") demand for diversified food products. The structural changes facilitated by PNAE modified the parameters within which women participate in agricultural activities and farm household decision-making. In supporting the process of farm diversification, PNAE benefited women's empowerment by creating the conditions for women to pursue productive activities, such as growing food products for PNAE, and make strategic choices including decision-making regarding productive activities and control over income.

The changes brought by PNAE would have been difficult to achieve without the social movements that prompted its redesign in the 2000s. By institutionalizing a guaranteed right to a market for family farmers, PNAE massified the efforts of social movements to support the family farming sector in Brazil (Grisa and Schneider, 2014). Women's empowerment was also bolstered by collective solidarity created by social groups, which had been supporting conditions for social change even before PNAE was redesigned. In our study, women who participated in social movements were more empowered and their households were more likely to participate in PNAE, possibly because participation in social movements increased their self-confidence, self-determination, and ability to pursue 
activities they value (Ibrahim and Alkire, 2007; Alkire, 2008). For instance, social movements focused on agroecological knowledge may contribute to women's empowerment by supporting peerto-peer knowledge sharing, training and workshops, thereby supporting women's confidence on their own knowledge base (Sumner and Llewelyn, 2011). However, it must be noted that agroecological social movements have not always been consciously feminist. Reaching the point in which some of these social movements embraced a feminist agenda is the result of long endured struggles and efforts of women within these movements (Butto, 2017).

PNAE enabled households to transition from input-intensive monocultures to diversified farming systems (e.g., horticulture) and to increase the size of horticulture plots (Valencia et al., 2019). These two key changes shifted women's role from tending a home garden for household consumption to involvement in a primary household economic activity. Other studies in Brazil have shown that a similar targeted public food procurement program-Programa de Aquisição de Alimentos, or the Program for Food Acquisition-also enabled female farmers to pursue and achieve economic autonomy (dos Santos et al., 2018). These outcomes are key for women's contribution to family income, although often within a context of subordination and a welldefined gender division of labor (Lopes Barbosa, 2017). Despite evidence for women's higher participation in, and decisionmaking about, productive activities in households involved in programs such as PNAE, registration data suggests that women's participation in such programs is low. This is likely because male heads of household are the ones who officially register for these programs (Siliprandi and Cintrão, 2011).

Our findings are consistent with other studies reporting that agroecological farming can more equitably distribute power and labor between men and women (Hall and Mogyorody, 2007; Bodapati and Chander, 2011; Sumner and Llewelyn, 2011). Gendered knowledge may help explain why women's participation is higher in diversified production systems, particularly those managed with agroecological practices. Knowledge about production systems and their management may differ between men and women due to gendered roles, a result of the division of household tasks and sometimes farming separate plots. In conventional agriculture, which is often mechanized and dominated by low diversity cultivation of cash crops, men tend to control both productive knowledge and decision-making (Momsen, 2004; Kawarazuka et al., 2019). Dividing resources and responsibilities in this way reflects gendered power relations in the use and control of resources (Rocheleau et al., 1996; Rocheleau, 2005).

PNAE supports a process of farm diversification (Valencia et al., 2019), for which women's empowerment played a crucial part. Across all farms, we found that when women were absent from decision-making, agrobiodiversity was lower and farmers relied less on agroecological practices. On the other hand, when both men and women were involved in decisionmaking, they jointly managed higher levels of agrobiodiversity while increasing use of agroecological practices. This may be because the complexity of management systems increases as agrobiodiversity increases, as does the knowledge required about ecological interactions among crop species and between crop and wild species (Kremen et al., 2012; Pauli et al., 2012). When men and women have complementary, rather than redundant, knowledge about agricultural production, joint decision-making may allow the household to manage more complex, knowledgeintensive systems. Higher complexity may also translate to higher labor demands, which requires the involvement of more family members. Joint decision-making demonstrates that a transition toward agroecology requires the integration of experiences and knowledge from different family members who manage different plots, thereby breaking the "management monopoly" that men often hold (Siliprandi, 2015a). While joint decisionmaking implies equal say between spouses, Acosta et al. (2019) caution against assuming that joint decision-making is equally balanced. In their study, they found that women reported joint decision-making more often than men in the same households. While denoting a certain level of perceived agency, this result also signals conflicting perceptions of participation and power dynamics. Although we cannot eliminate this possibility from our own study, based on field observations and key informant interviews, we are confident that joint decision-making in this study accurately captured women's bargaining power in an intrahousehold process of negotiation.

Gender dynamics related to technology were reflected in our study in the differences in women's participation in decision-making between horticulture and grain monocropping. Agricultural mechanization-the adoption of labor-saving machines and tools for agriculture-has been shown to alienate women from agricultural activities (Jellison, 1993; Niskanen, 2001; Hall and Mogyorody, 2007). Technology may accentuate gender inequities by introducing machines, such as tractors, that result in men gaining power both materially and symbolically. Often, labor saving technologies, such as plowing, harrowing, and weeding machines, are only used by men because both men and women perceive those machines as physically too heavy for women, or too difficult or dangerous to handle (Kawarazuka et al., 2019). This is partly because technological innovations are often proposed or developed by male researchers in response to priorities identified by male farmers, resulting in the production and reproduction of male-oriented technology (Kline and Pinch, 1996; Kawarazuka et al., 2019). In this way, technology influences, and is influenced by, gender relations (Wajcman, 2010). From a normative perspective, women's decision-making and capacity to participate in productive decisions should not be constrained by commodity and grain markets. Kawarazuka et al. (2019) argues that rather than trying to increase women's acess to existing male-oriented technologies, agricultural development interventions need to identify the needs of women and other marginalized groups (e.g., ethnic minorities) and (re)design tehcnologies with these groups' needs as priorities. Consulting women in the design process and adjusting technologies to their needs and priorities can ensure higher adoption of time-saving technologies by both men and women (Kawarazuka et al., 2018). This may reduce the amplifying effect that some forms of technological innovation can have on gender inequity and power imbalances. 


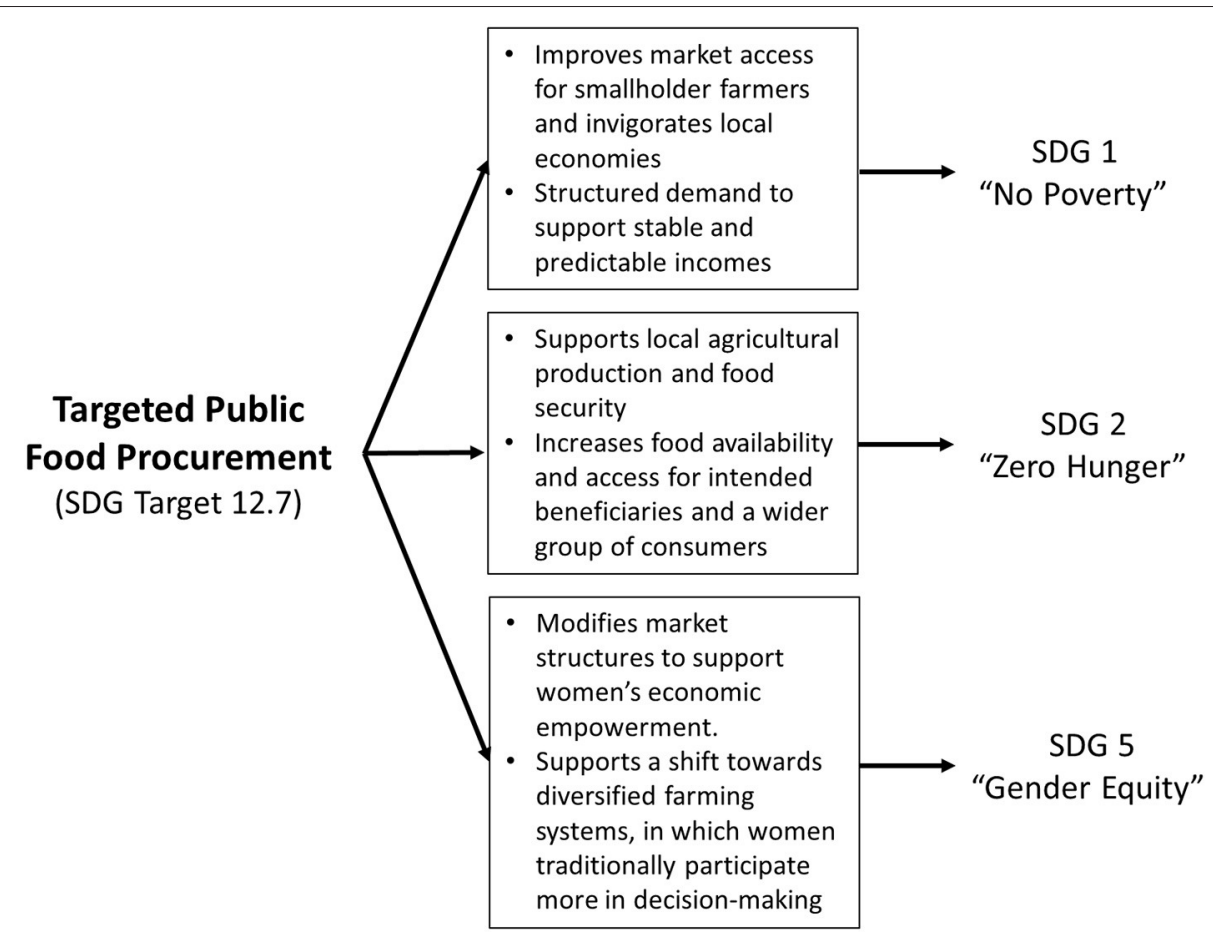

FIGURE 4 | Targeted public food procurement programs, such as Brazil's National School Feeding Program, may contribute to sustainable consumption and production patterns (SDG 12, target 12.7). Targeted public food procurement may also support other Sustainable Development Goals, particularly SDG 1 "No Poverty," SDG 2 "Zero Hunger," and SDG 5 "Gender Equality".

Women's higher level of participation in productive activities, although a positive indicator of empowerment, may have negative implications on women's time allocation. We did not apply the A-WEAI module on time allocation, which would have allowed us to examine whether changes in women's roles in productive activities in agriculture resulted in more total working hours. Increasing the number of hours worked in the field does not necessarily release women from their usual household work, which means that they may experience a double workday (Allen and Sachs, 2007; Brumer, 2008). Although women's empowerment is often associated with improved maternal and child health (van den Bold et al., 2013; Cunningham et al., 2015; Pratley, 2016), an increased involvement in productive activities may come at a trade off with time spent on care practices, such as breastfeeding, negatively affecting child nutrition (Barrios and Hoffman, 2012; Jones, 2014; Cunningham et al., 2015). Furthermore, studies that have also found higher levels of household decision-making and control over income among women who participate in social movements, reported that these benefits are offset by time poverty, as women continue to bear a disproportionate share of domestic labor obligations (Lyon et al., 2017). Therefore, development interventions and programs such as PNAE should take into account the demands on women's time from the responsibilities of income-generating activities and other duties such as child rearing and household work (Koehler, 2016). Although our results suggest that women in households participating in PNAE are more empowered, the implications of potential changes in time allocation on their work burden and in other aspects of women's lives in the study sample require further study.

\section{Policy Implications}

Public procurement programs, such as PNAE, may support SDG 1 "No Poverty," SDG 2 "Zero Hunger," and SDG 5 "Gender Equality" while also providing a tangible pathway for implementing SDG 12, target 12.7, which promotes sustainable public procurement, but which is only vaguely phrased and does not provide effective guidance for implementation (Bengtsson et al., 2018; Figure 4). Realizing the full potential of public procurement will require a conducive regulatory framework to translate broader sustainability and development objectives into procurement rules and practices (Swensson and Tartanac, 2020).

By design, public procurement programs based on structured demand have the potential to serve broad development objectives, including supporting local and more sustainable agricultural production and increasing food security thereby addressing SDG 2 "Zero Hunger." These programs may influence the structural determinants of food security by reducing food price volatility (an issue for both urban consumers and rural producers) and maintaining dynamic domestic food supply chains (Ashe and Sonnino, 2013)., Targeted public food procurement may indirectly benefit food security by increasing food availability and access for a wider group of consumers, including farmers themselves and the local community (Coles, 2013; FAO, 2018). For example, by focusing on diversified food products, these programs contribute to achieving "Zero 
Hunger" among program beneficiaries, while also creating positive spillover effects in communities by increasing the local and regional supply of diversified food products (Valencia et al., 2019).

Public procurement programs may also help address SDG 1 "No Poverty" by improving market access for disadvantaged groups and invigorating local economies. Because they are targeted programs, they reduce barriers to entry and transaction costs for the targeted disadvantaged groups (e.g., smallholder farmers) (Sumberg and Sabates-Wheeler, 2010), and thus reduce the risks of market participation. For instance, Brazil adapted its legal frameworks to allow public procurement calls to favor local, small-scale farmers (Swensson, 2015). Structured demand may also support the process of economic localization by linking local producers (family farmers) with local consumers (e.g., procurement beneficiaries).

Finally, public procurement could directly address SDG 5 "Gender Equality" by enacting "gender-responsive procurement," defined by UN Women-the UN organization dedicated to gender equity-as "the selection of goods, civil works or services that take into account their impact on gender equality and women's empowerment" (U. N. Women, 2020). Public procurement may also support women's economic empowerment by creating more inclusive access to supply chains and increasing their participation in labor markets (Harris Rimmer, 2017). One way of removing barriers for women to participate in public procurement is to preferentially engage enterprises owned by women (Chin, 2017). For example, Brazil's Food Acquisition Program, established in 2011, requires that at least $40 \%$ of purchases come from female farmers in order to strengthen gender equity and address the "invisibility" of women in public procurement policies (dos Santos et al., 2018).

\section{CONCLUSION}

Gender equity is now recognized as central to sustainable development, as highlighted in SDG 5 in the United Nations Agenda 2030. However, women still face significant constraints in accessing and controlling productive resources important for agricultural livelihoods. In this study, we showed that public procurement is a promising policy mechanism for enhancing women's empowerment in agriculture, in combination with social movements that are inclusive of women. Procurement programs such as PNAE, which target family farmers, may support women's empowerment by creating local markets for a wide range of food products, thereby valuing diversified production systems which are more inclusive of women. By

\section{REFERENCES}

Abreu, L. S., Bellon, S., Brandenburg, A., Ollivier, G., Lamine, C., Darolt, M. R., et al. (2012). Relações entre agricultura orgânica e agroecologia: desafios atuais em torno dos princípios da agroecologia. Desenvolv. e Meio Ambient. 26, 143-160. doi: 10.5380/dma.v26i0. 26865 supporting women's empowerment at the household level, the interplay between PNAE and social movements has the potential for positive feedbacks that increase gender equity, indicating that interactions between grassroots movements and government institutions can create more equitable and sustainable food systems.

\section{DATA AVAILABILITY STATEMENT}

The raw data supporting the conclusions of this article will be made available by the authors, without undue reservation.

\section{ETHICS STATEMENT}

The studies involving human participants were reviewed and approved by University of Michigan IRB. Written informed consent for participation was not required for this study in accordance with the national legislation and the institutional requirements.

\section{AUTHOR CONTRIBUTIONS}

VV: conceptualization, methodology, investigation, data curation, formal analysis, visualization, and writing-original draft. HW and AJ: writing-reviewing and editing. JB: conceptualization, methodology, writing-reviewing and editing, funding acquisition, and supervision. All authors contributed to the article and approved the submitted version.

\section{FUNDING}

This research was supported by the School for Environment and Sustainability, the Graham Institute, and the Crosby Fellowship at the University of Michigan.

\section{ACKNOWLEDGMENTS}

The authors thank the farmers who contributed to this study and the logistical support provided by CRESOL, Epagri, and the Farmer's Union in Curitibanos. We would like to thank Dr. Joshua Farley at the University of Vermont, Dr. Zilma Peixe at the Universidade Federal de Santa Catarina in Curitibanos, Dr. Abdon Schmitt at the Universidade Federal de Santa Catarina in Florianopolis, and Centro Vianei for their valuable guidance. The authors are grateful for the support of field assistants Diego Correa, Danilo Macedo, Aleixa de Souza, Kathrine de Souza, Leticia Pereira, and Laura Vezzani. L., et al. (2019). What does it mean to make a 'Joint' decision? unpacking intrahousehold decision making in agriculture: implications for policy and practice. J. Dev. Stud. 56, 1210-1229. doi: 10.1080/00220388.2019.1650169

Agarwal, B. (2014). Food sovereignty, food security and democratic choice: critical contradictions, difficult conciliations. J. Peasant Stud. 41, 1247-1268. doi: $10.1080 / 03066150.2013 .876996$ 
Alkire, S. (2008). Concepts and Measures of Agency. OPHI Working Paper 9, Oxford: University of Oxford. doi: 10.1093/acprof:oso/9780199239115.003.0025

Alkire, S., Meinzen-Dick, R., Peterman, A., Quisumbing, A., Seymour, G., and Vaz, A. (2013). The women's empowerment in agriculture index. World Dev. 52, 71-91. doi: 10.1016/j.worlddev.2013.06.007

Allen, P., and Sachs, C. (2007). Women and food chains 1 : the gendered politics of food. Int. J. Sociol. Food Agric. 15, 1-23. Available online at: https://doi.org/10. 48416/ijsaf.v15i1.424

Alsop, R., Bertelsen, M., and Holland, J. (2006). Empowerment in Practice From Analysis to Implementation. Washington, DC: World Bank. doi: 10.1596/978-0-8213-6450-5

Ashe, L. M., and Sonnino, R. (2013). At the crossroads: new paradigms of food security, public health nutrition and school food. Public Health Nutr. 16, 1020-1027. doi: 10.1017/S1368980012004326

Barrett, H. R., Browne, A. W., Harris, P. J. C., and Cadoret, K. (2012). Smallholder farmers and organic certification: accessing the eu market from the developing world. Biol. Agric. Horicult. 19, 183-199. doi: 10.1080/01448765.2001. 9754920

Barrios, P. L., and Hoffman, D. J. (2012). Relationship Between Household Strcture, Maternal Autonomy and Undernutrition in Brazilian Children (dissertation). New Brunswick, NJ: The State University of New Jersey. doi: 10.1096/fasebj.27.1_supplement.618.7

Bengtsson, M., Alfredsson, E., Cohen, M., Lorek, S., and Schroeder, P. (2018). Transforming systems of consumption and production for achieving the sustainable development goals: moving beyond efficiency. Sustain. Sci. 13, 1533-1547. doi: 10.1007/s11625-018-0582-1

Benjamini, Y., and Hochberg, Y. (1995). Controlling the false discovery rate: a practical and powerful approach to multiple testing. J. R. Stat. Soc. Ser. B 57, 289-300. doi: 10.1111/j.2517-6161.1995.tb02031.x

Bezner Kerr, R., Hickey, C., Lupafya, E., and Dakishoni, L. (2018). Repairing rifts or reproducing inequalities? Agroecology, food sovereignty, and gender justice in Malawi. J. Peasant Stud. 6150, 1499-1518. doi: 10.1080/03066150.2018. 1547897

Blesh, J., and Wittman, H. (2015). "Brasilience:" assessing resilience in land reform settlements in the Brazilian Cerrado. Hum. Ecol. 43, 531-546. doi: 10.1007/s10745-015-9770-0

Bodapati, S., and Chander, M. (2011). Organic agriculture: a way forward to achieve gender equality in India. J. Org. Syst. 6, 13-19.

Brammer, S., and Walker, H. (2011). Sustainable procurement in the public sector: an international comparative study. Int. J. Oper. Prod. Manag. 31, 452-476. doi: 10.1108/01443571111119551

Brumer, A. (2008). Gender relations in family-farm agriculture and rural-urban migration in Brazil. Lat. Am. Perspect. 35, 11-28. doi: $10.1177 / 0094582$ X08326012

Butto, A. (2017). Movimentos Sociais De Mulheres Rurais No Brasil : A Construção Do Sujeito Feminista (dissertation). Recife: Universidade Federal de Pernambuco.

Butto, A. (2019). "March of the daisies: subject, agriculture, and the state," in State Capitalism Under Neoliberalism: The Case of Agriculture and Food in Brazil, eds A. Bonanno and J. S. Barbosa Cavalcant (Lanham, MD: The Rowman \& Littlefield), 1-113.

Chin, K. (2017). The Power of Procurement: How to Source from Women-Owned Businesses. New York, NY: UN Women.

Coles, C. (2013). What is Known About the Impact of Structured Demand Activities on Resilient Food Systems? London: Overseas Development Institute. Available online at: https://www.odi.org/sites/odi.org.uk/files/odi-assets/publicationsopinion-files/8618.pdf (accessed May 20, 2020).

Commandeur, D., and Casey, K. (2016). Structured Demand Markets and Smallholder Farmers: Relevance and Access. SNV. Available online at: https:// agriknowledge.org/downloads/zp38wc67w (accessed September 20, 2020).

Cunningham, K., Ruel, M., Ferguson, E., and Uauy, R. (2015). Women's empowerment and child nutritional status in South Asia: a synthesis of the literature. Matern. Child Nutr. 11, 1-19. doi: 10.1111/mcn.12125

Deere, C. D. (2003). Women's land rights and rural social movements in the Brazilian agrarian reform. J. Agrar. Chang. 3, 257-288. doi: $10.1111 / 1471-0366.00056$
Deere, C. D. (2017). Women's land rights, rural social movements, and the state in the 21st-century Latin American agrarian reforms. J. Agrar. Chang. 17, 258-278. doi: 10.1111/joac. 12208

dos Santos, Á. O., Wagner Silva, D., and Quaresma, E. S. (2018). "Women farmers and the PAA: participation in the productive process and commercialization," in 3rd International Conference "Agriculture and food in an urbanizing society" (Porto Alegre, Brazil: Universidade Federal do Rio Grande do Sul), $1-8$.

FAO. (2011). Women in Agriculture: Closing the Gender Gap for Development. Rome: FAO Available online at: http://files/4686/FAO-2011-Women/ inagriculture/closing/thegender/gapfor/d.pdf (accessed October 31, 2020).

FAO. (2014). Scaling Up the Brazilian School Feeding model: Using South-South Cooperation to Share Brazil's Experience of School Feeding in Latin America and the Caribbean. Rome: Food and Agriculture Organization. Available online at: http://www.fao.org/3/a-h0050e.pdf (accessed September 20, 2020).

FAO. (2018). Strengthening Sector policies for Better Food Security and Nutrition Results: Public Food Procurement. Policy Guidance Note. Rome. Available online at: http://www.wipo.int/amc/en/mediation/rules (accessed April 11, 2019).

FAO. (2020). The Female Face of Farming. Rome. Available online at: http:// www.fao.org/gender/resources/infographics/the-female-face-of-farming/en/ (accessed January 17, 2020).

Fundo Nacional de Desenvolvimento da Educacao (FNDE) (2018) Dados da Agricultura Familiar. Available online at: https://www.fnde.gov.br/programas/ pnae/pnae-consultas/pnae-dados-da-agricultura-familiar

Garibaldi, L. A., Carvalheiro, L. G., Vaissière, B. E., Gemmill-Herren, B., Hipólito, J., Freitas, B. M., et al. (2016). Mutually beneficial pollinator diversity and crop yield outcomes in small and large farms. Science 351, 388-391. doi: 10.1126/science.aac7287

Gates, M. F. (2014). Putting women and girls at the center of development. Science 345, 1273-1275. doi: 10.1126/science. 1258882

Grisa, C., and Isopo Porto, S. (2015). "Dez anos de PAA: As contribuições e os desafios para o desenvolvimento rural," in Políticas Públicas de Desenvolvimento Rural NO BRASIL, eds. C. Grisa, and S. Schneider (Porto Alegre, Brazil: Editora da UFRGS), $155-180$.

Grisa, C., and Schneider, S. (2014). Três gerações de políticas públicas para a agricultura familiar e formas de interação entre sociedade e estado no Brasil. Rev. Econ. e Sociol. Rural 52, 125-146. doi: 10.1590/S0103-200320140006 00007

Guerra, J., Blesh, J., Schmitt, A., and Wittman, H. (2017). Pathways to agroecological management through mediated markets in Santa Catarina, Brazil. Elem. Sci. Anth. 5, 1-16. doi: 10.1525/elementa.248

Hall, A., and Mogyorody, V. (2007). Organic farming, gender, and the labor process. Rural Sociol. 72, 289-316. doi: 10.1526/003601107781170035

Harris Rimmer, S. (2017). Gender-Smart Procurement Policies for Driving Change. London: Chatham House.

Head, S., Zweimueller, S., Marchena, C., and Hoel, E. (2014). Women's Lives and Challenges : Equality and Empowerment Since 2000. Maryland, USA. Available online at: www.dhsprogram.com (accessed September 22, 2020).

Ibrahim, S., and Alkire, S. (2007). Agency and empowerment: a proposal for internationally comparable indicators. Oxford Dev. Stud. 35, 379-403. doi: 10.1080/13600810701701897

Instituto Brasileiro de Geografia e Estadisticas (IBGE) (2006). Censo Agropecuario, Available online at: http://www.sidra.ibge.gov.br/bda/acervo/acervo2.asp?ti= $1 \& \mathrm{tf}=99999 \& \mathrm{e}=\mathrm{v} \& \mathrm{p}=\mathrm{CA} \& \mathrm{z}=\mathrm{t} \& \mathrm{o}=11$

Instituto Brasileiro de Geografia e Estadísticas (IBGE) (2013). Segurança Alimentar. Report. Available online at: http://www.ibge.gov.br/home/ presidencia/noticias/imprensa/ppts/000000201124121120142_43818986695. pdf

Jellison, K. (1993). Entitled to Power: Farm Women and Technology, 1913-1963. North Carolina: University of North Carolina Press.

Johnson, N., Balagamwala, M., Pinkstaff, C., Theis, S., and Meinzen-dick, R. (2018). How do agricultural development projects empower women? Link. Strat. Expect. Outcomes. 3, 1-19.

Jones, A. D. (2014). The production diversity of subsistence farms in the Bolivian Andes is associated with the quality of child feeding practices as measured by a validated summary feeding index. Public Health Nutr. 18, 329-342. doi: $10.1017 /$ S1368980014000123 
Kabeer, N. (1999). Resources, agency, achievements: reflections on the measurement of women's empowerment. Dev. Change 30, 435-464. doi: $10.1111 / 1467-7660.00125$

Kabeer, N. (2010). Women's empowerment, development interventions and the management of information flows. IDS Bull. 41, 105-113. doi: 10.1111/j.1759-5436.2010.00188.x

Kawarazuka, N., Anh, N. T. H. I. V. A. N., Thai, V. U. X., and Thuong, P. H. U. U. (2019). “A Bird Locked in a Cage": Hmong young women's lives after marriage in northern Vietnam. Gender Agric. Agrar. Transform. Chang. Relations Afr. Lat. Am. Asia 111-126. doi: 10.4324/9780429427381-7

Kawarazuka, N., Prain, G., Forsythe, L., Mayanja, S., Mudege, N. N., Babini, C., et al. (2018). Gender in Agricultural Mechanization: Key Guiding Questions. Lima, Peru. Available online at: http://www.vedcouganda.org (accessed April 13, 2020).

Kilic, T., Winters, P., and Carletto, C. (2015). Gender and agriculture in subSaharan Africa: introduction to the special issue. Agric. Econ. 46, 281-284. doi: 10.1111 /agec. 12165

Kindt, R., and Coe, R. (2005). Tree Diversity Analysis. A Manual and Software for Common Statistical Methods for Ecological and Biodiversity Studies. Nairobi: World Agroforestry Centre (ICRAF).

Kline, R., and Pinch, T. (1996). Users as agents of technological change: the social construction of the automobile in the rural United States. Technol. Cult. 37, 763-795. doi: 10.2307/3107097

Koehler, G. (2016). Tapping the Sustainable Development Goals for progressive gender equity and equality policy? Dender Dev. 24, 53-68. doi: 10.1080/13552074.2016.1142217

Kremen, C., Iles, A., and Bacon, C. (2012). Diversified farming systems: an agroecological, systems-based alternative to modern industrial agriculture. Ecol. Soc. 17, 288-306. doi: 10.5751/ES-05103-170444

Leach et al., Leach, M., Reyers, B., Bai, X., Brondizio, E. S., Cook, C., Díaz, S., et al. (2018). Equity and sustainability in the anthropocene: a socialecological systems perspective on their intertwined futures. Glob. Sustain. 1, 1-13. doi: $10.1017 /$ sus.2018.12

Lopes Barbosa, T. (2017). The Process of Empowerment of Rural Women and the Programa Nacional de Alimentação Escolar (PNAE): the Case of Viçosa-MG. (Master's thesis). Viçosa, Minas Gerais: Universidade Federal de Viçosa.

Lovell, P. A. (2000). Race, gender and regional labor market inequalities in Brazil. Rev. Soc. Econ. 58, 277-293. doi: 10.1080/00346760050132337

Lyon, S., Mutersbaugh, T., and Worthen, H. (2017). The triple burden: the impact of time poverty on women's participation in coffee producer organizational governance in Mexico. Agric. Human Values 34, 317-331. doi: 10.1007/s10460-016-9716-1

Malapit, H., Kovarik, C., Sproule, K., Meinzen-Dick, R., and Quisumbing, A. (2015). Instructional Guide on the Abbreviated Women's Empowerment in Agriculture Index (A-WEAI). International Food Policy Research Institute. Available online at: http://files/4692/Malapit et al. - Instructional Guide on the Abbreviated Women's Emp.pdf

Malapit, H., and Quisumbing, A. (2015). What dimensions of women's empowerment in agriculture matter for nutrition in Ghana? Food Policy 52, 54-63. doi: 10.1016/j.foodpol.2015.02.003

Malhotra, A., and Schuler, S. (2005). "Chapter 3 women's empowerment as a variable in international development," in Measuring Empowerment CrossDisciplinary Perspectives, ed. Narayan (Washington, DC: World Bank), 1-496.

Martínez-Torres, M. E., and Rosset, P. (2010). La Vía Campesina: the birth and evolution of a transnational social movement. J. Peasant Stud. 37, 149-175. doi: 10.1080/03066150903498804

Medina, G., Almeida, C., Novaes, E., Godar, J., and Pokorny, B. (2015). Development conditions for family farming: lessons from Brazil. World Dev. 74, 386-396. doi: 10.1016/j.worlddev.2015.05.023

Mendonça Leão, M., and Maluf, R. S. (2003). Effective Public Policies and Active Citizenship: Brazil's Experience of Building a Food and Nutrition Security System. Brasilia: Abrandh and Oxfam.

Momsen, J. H. (2004). “Gender and development," in Gender and Developmen (London; New York, NY: Routledge).

Müller, A. L., Fialho, M. A. V., and Schneider, S. (2007). A inovação institucional e a atuação dos atores locais na implementação do Programa de Aquisição de Alimentos no Rio Grande do Sul. Soc. e Desenvolv. Rural. 1, 1-21.
Narayan, D., ed. (2005). Measuring Empowerment: Cross-Disciplinary Perspectives Washington, DC: World Bank. doi: 10.1037/e597202012-001

Nehring, R., Miranda, A., and Howe, A. (2017). Making the case for institutional demand: supporting smallholders through procurement and food assistance programmes. Glob. Food Sec. 12, 96-102. doi: 10.1016/j.gfs.2016.0 9.003

Niskanen, K. (2001). Gender economics in action: rural women's economic citizenship in Finland during the twentieth century. J. Womens. Hist. 13, 132-152. doi: 10.1353/jowh.2001.0054

Oakley, E., and Momsen, J. H. (2005). Gender and agrobiodiversity: a case study from Bangladesh. Geogr. J. 171, 195-208. doi: 10.1111/j.1475-4959.2005.00160.x

OECD (2017). "Size of public procurement," in Government at a Glance 2017 (Paris).

Oliver, B. (2016). "The Earth Gives Us So Much": agroecology and rural women's leadership in Uruguay. Cult. Agric. Food Environ. 38, 38-47. doi: 10.1111/cuag.12064

Pauli, N., Barrios, E., Conacher, A. J., and Oberthür, T. (2012). Farmer knowledge of the relationships among soil macrofauna, soil quality and tree species in a smallholder agroforestry system of western Honduras. Geoderma 189-190, 186-198. doi: 10.1016/j.geoderma.2012.05.027

Pratley, P. (2016). Associations between quantitative measures of women's empowerment and access to care and health status for mothers and their children: a systematic review of evidence from the developing world. Soc. Sci. Med. 169, 119-131. doi: 10.1016/j.socscimed.2016. 08.001

Prévost, H. (2019). Agroecologia, uma ciência 'norma(l)cho'? sob as escrituras científicas, o androcentrismo. Rev. Cad. Ciências Sociais da UFRPE. 2, 25-52.

Quisumbing, A. (2003). Household Decisions, Gender, and Development: A Synthesis of Recent Research. Available online at: http://ebrary.ifpri.org/cdm/ ref/collection/p15738coll2/id/129647 (accessed October 8, 2019).

Rocha, C. (2007). Food insecurity as market failure: a contribution from economics. J. Hunger Environ. Nutr. 1, 5-22. doi: 10.1300/J477v01n $04 \_02$

Rocha, C., Burlandy, L., and Maluf, R. (2012). Small farms and sustainable rural development for food security: the Brazilian experience. Dev. South. Afr. 29, 519-529. doi: 10.1080/0376835X.2012.715438

Rocheleau, D. (2005). Gender, Environment and Development. London; New York, NY: Routledge.

Rocheleau, D., Thomas-Slayter, B., and Wangari, E., eds. (1996). Feminist Political Ecology: Global Issues and Local Experiences. London: Routledge.

Rosset, P., and Martínez-Torres, M. E. (2012). Rural social movements and agroecology: context, theory, and process. Ecol. Soc. 17:17. doi: 10.5751/ES-05000-170317

Rosset, P., Sosa, B. M., Jaime, A. M. R., and Lozano, D. R. Á. (2011). The Campesino-to-Campesino agroecology movement of ANAP in Cuba: social process methodology in the construction of sustainable peasant agriculture and food sovereignty. J. Peasant Stud. 38, 161-191. doi: 10.1080/03066150.2010.538584

Schipanski, M. E., MacDonald, G. K., Rosenzweig, S., Chappell, M. J., Bennett, E. M., Bezner Kerr, R., et al. (2016). Realizing resilient food systems. Bioscience 66 600-610. doi: 10.1093/biosci/biw052

Schneider, S., Shiki, S., and Belik, W. (2010). Rural development in Brazil: overcoming inequalities and building new markets. Riv. di Econ. Agrar. 65, 225-259.

Schneider, S., Thies, V., Grisa, C., and Belik, W. (2016). "Potential of public purchases as markets for family farming," in Advances in Food Security and Sustainability, ed. D. Barling (Burlington: Academic Press), 69-95. Available at: https://www.researchgate.net/publication/309710349_Potential_of_Public Purchases_as_Markets_for_Family_Farming (accessed September 22, 2020). doi: 10.1016/bs.af2s.2016.09.003

SEBRAE (2013). Santa Catarina em Números. Florianópolis, SC. Available online at: https://www.sebrae.com.br/Sebrae/Portal\%20Sebrae/Anexos/Relatorio \%20Estadual.pdf

Sidaner, E., Balaban, D., and Burlandy, L. (2013). The Brazilian school feeding programme: an example of an integrated programme in support of food and nutrition security. Public Health Nutr. 16, 989-994. doi: $10.1017 /$ S1368980012005101 
Siliprandi, E. (2015a). "A AGROECOlOGIA E O PROTAGONISMO DAS AGRICULTORAS E dos AGRICULTORES," in Mulheres e Agroecologia: Transformando o Campo, as Florestas e as Pessoas (Rio de Janeiro: Universidade Federal do Rio de Janeiro), 81-110.

Siliprandi, E. (2015b). "As mulheres no movimento agroecologico Brasilieiro," in Mulheres e Agroecologia: Transformando o Campo, as Florestas e as Pessoas (Rio de Janeiro: Universidade Federal do Rio de Janeiro), 111-184.

Siliprandi, E., and Cintrao, R. (2015). "Mulheres rurais e políticas públicas no Brasil: abrindo espaços para o seu reconhecimento como cidadãs," in Políticas Públicas de Desenvolvimento Rural No Brasil, eds. C. Grisa, and S. Schneider (Porto Alegre: UFRGS Editora) 571-594.

Siliprandi, E., and Cintrão, R. P. (2011). As mulheres agricultoras no Programa de Aquisição de Alimentos (PAA). Segurança Aliment. e Nutr. 18, 12-32. doi: $10.20396 /$ san.v18i2.8634675

Sumberg, J., and Sabates-Wheeler, R. (2010). Working Paper Linking Agricultural Development to School Feeding. Brighton: Institute of Development Studies. Available online at: http://files/4463/Sumberg and Sabates-wheeler - 2010 Working Paper Linking Agricultural Development to.pdf.

Sumberg, J., and Sabates-Wheeler, R. (2011). Linking agricultural development to school feeding in sub-Saharan Africa: theoretical perspectives. Food Policy 36, 341-349. doi: 10.1016/j.foodpol.2011.03.001

Sumner, J., and Llewelyn, S. (2011). Organic solutions? Gender and organic farming in the age of industrial agriculture. Capital. Nat. Soc. 22, 100-118. doi: $10.1080 / 10455752.2010 .546659$

Swensson, L. (2015). Institutional Procurement of Food From Smallholder Farmers: The Case of Brazil. Food and Agriculture Organization. Available online at: http://files/4503/a-bc569e.pdf (accessed December 11, 2020).

Swensson, L., and Tartanac, F. (2020). Public food procurement for sustainable diets and food systems: the role of the regulatory framework. Glob. Food Sec. 25:100366. doi: 10.1016/j.gfs.2020.100366

Swensson, L. F. J., Hunter, D., Schneider, S., and Tartanac, F. (2021). Public food procurement as a game changer for food system transformation. Lancet Planet. Heal. 5, e495-e496. doi: 10.1016/S2542-5196(21)00176-5

Takagi, M., Sanches, A., and da Silva, J. G. (2014). Programa de Aquisição de Alimentos: um Embaixador do Brasil Contra a Fome. PAA: 10 Anos de Aquisição de Alimentos. Brasilia: Ministerio do Desenvolvimento Social e Combate à Fome.

Trevilla Espinal, D. L., Soto Pinto, M. L., Morales, H., and Estrada-Lugo, E. I. J. (2021). Feminist agroecology: analyzing power relationships in food systems. Agroecol. Sustain. Food Syst. 45, 1029-1049. doi: $10.1080 / 21683565.2021 .1888842$

UNDP. (2016). ANÁLISE GERAL DA TENDÊNCIA DE EVOLUÇÃO DO IDHM NO BRASIL. UNDP. Available online at: http://atlasbrasil.org.br/2013/data/ rawData/RadarIDHM_Analise.pdf
U. N. Women. (2020). Procurement: Gender-Responsive Procurement. Available online at: https://www.unwomen.org/en/about-us/procurement/genderresponsive-procurement (accessed November 1, 2019).

Valencia, V., Wittman, H., and Blesh, J. (2019). Structuring markets for resilient farming systems. Agron. Sustain. Dev. 39:25. doi: 10.1007/s13593-0190572-4

van den Bold, M., Quisumbing, A., and Gillespie, S. (2013). Women's Empowerment and Nutrition: An Evidence Review. Available online at: https://books.google.nl/books?hl=en\&lr=\&id=GbDvAQAAQBAJ\&oi= fnd\&pg=PR5\&dq=women $\$+\$$ empowerment $\$+\$$ nutrition $\$+\$$ health\&ots= jisYubN7yI\&sig=uqSRmUYhFaUM9n-ly1KldRlvBsk\&redir_esc=y\#v= onepage \&q=women empowerment nutrition health\& $\mathrm{f}=$ false (accessed March 20, 2020). doi: 10.2139/ssrn.2343160

Wajcman, J. (2010). Feminist theories of technology. Cambridge J. Econ. 34, 143-152. doi: 10.1093/cje/ben057

Wezel, A., Casagrande, M., Celette, F., Vian, J.-F., Ferrer, A., and Peigné, J. (2014). Agroecological practices for sustainable agriculture. A review. Agron. Sustain. Dev. 34, 1-20. doi: 10.1007/s13593-013-0180-7

Wittman, H., and Blesh, J. (2017). Food sovereignty and fome zero: connecting public food procurement programmes to sustainable rural development in Brazil. J. Agrar. Chang. 17, 81-105. doi: 10.1111/joac.12131

Wolford, W. (2010). This Land Is Ours Now: Social Mobilization and the Meanings of Land in Brazie. North Carolina: Duke University Press. doi: $10.1515 / 9780822391074$

World Bank. (2011). Gender Equality and Development. Washington, DC: World Bank

Conflict of Interest: The authors declare that the research was conducted in the absence of any commercial or financial relationships that could be construed as a potential conflict of interest.

Publisher's Note: All claims expressed in this article are solely those of the authors and do not necessarily represent those of their affiliated organizations, or those of the publisher, the editors and the reviewers. Any product that may be evaluated in this article, or claim that may be made by its manufacturer, is not guaranteed or endorsed by the publisher.

Copyright (๑) 2021 Valencia, Wittman, Jones and Blesh. This is an open-access article distributed under the terms of the Creative Commons Attribution License (CC BY). The use, distribution or reproduction in other forums is permitted, provided the original author(s) and the copyright owner(s) are credited and that the original publication in this journal is cited, in accordance with accepted academic practice. No use, distribution or reproduction is permitted which does not comply with these terms. 